\title{
The Equilateral Agility Concept as Mediating Variable in Relationship between IT-Strategy Alignment and Sustainable Competitive Advantage
}

\author{
Lutfi Nurcholis $\bowtie$, Budhi Cahyono \\ Management Program, Universitas Islam Sultan Agung, Semarang, Indonesia
}

\section{Info Article}

History Article:

Submitted 13 September 2019

Revised 6 November 2019

Accepted 7 November 2019

\section{Keywords:}

IT-Strategy Alignment; Respon-

siveness; Operational Flexibility;

Business Relationship; Sustainable

Competitive Advantage.

\begin{abstract}
This paper aims to investigate the effect of IT-strategy alignment, responsiveness, operational flexibility, and business relationship on sustainable competitive advantage and the mediating effect of responsiveness, operational flexibility, and business relationship in relationships between IT-strategy alignment and sustainable competitive advantage. Data were collected from 189 Batik SME in Pekalongan and analyzed by using Structural Equation Modeling (SEM). The result shows that IT-strategy alignment significantly affects responsiveness. Responsiveness, operational flexibility, and also business relationship significantly affect sustainable competitive advantage. Furthermore, responsiveness, operational flexibility, and business relationship mediate the correlation of IT-strategy alignment and sustainable competitive advantage. Responsiveness, operational flexibility, and business relationship have the confidence and value that puts customers on every business decision. It encourages Batik SME to improve the sustainable competitive advantage based on the customers' expectations. IT-strategy alignment is essential to enhance responsiveness, operational flexibility, and business to gain a sustainable competitive advantage. That IT-strategy alignment can improve the sustainable competitive advantage of the Batik SME.
\end{abstract}

\section{Konsep Agility Equilateral sebagai Variabel Mediasi dalam Hubungan antara Penyelarasan TI-Strategi dan Keunggulan Kompetitif yang Berkelanjutan}

\begin{abstract}
Abstrak
Makalah ini bertujuan untuk menyelidiki pengaruh penyelarasan TI-strategi, daya tanggap, fleksibilitas operasional, dan hubungan bisnis pada keunggulan kompetitif berkelanjutan dan efek mediasi, fleksibilitas operasional, dan hubungan bisnis dalam hubungan antara penyelarasan strategi TI dan keunggulan kompetitif berkelanjutan. Data dikumpulkan dari 189 UKM Batik di Pekalongan dan dianalisis dengan menggunakan Structural Equation Modeling (SEM). Hasil penelitian menunjukkan bahwa penyelarasan strategi TI secara signifikan mempengaruhi daya tanggap. Daya tanggap, fleksibilitas operasional, dan juga hubungan bisnis secara signifikan mempengaruhi keunggulan kompetitif yang berkelanjutan. Selain itu, daya tanggap, fleksibilitas operasional, dan hubungan bisnis memediasi korelasi penyelarasan strategi TI dan keunggulan kompetitif berkelanjutan. Daya tanggap, fleksibilitas operasional, dan hubungan bisnis memiliki kepercayaan dan nilai yang menempatkan pelanggan pada setiap keputusan bisnis. Ini mendorong UKM Batik untuk meningkatkan keunggulan kompetitif yang berkelanjutan berdasarkan harapan pelanggan. Penyelarasan strategi TI sangat penting untuk meningkatkan daya tanggap, fleksibilitas operasional, dan hubungan bisnis untuk mendapatkan keunggulan kompetitif yang berkelanjutan. Penyelarasan strategi TI tersebut dapat meningkatkan keunggulan kompetitif berkelanjutan dari UKM Batik.
\end{abstract}

\section{JEL Classification: M3, M31}

How to Cite: Nurcholis, L., \& Cahyono, B. (2019). The Equilateral Agility Concept as Mediating Variable in Relationship between IT-Strategy Alignment and Sustainable Competitive Advantage. Jurnal Dinamika Manajemen, 10(2), 240-255. 
Lutfi Nurcholis \& Budhi Cahyono/ The Equilateral Agility Concept as Mediating Variable in Relationship....

\section{INTRODUCTION}

For several years the concept of IT governance has become the main agenda of the organization or company. Many projects regarding IT governance have started in various companies, to achieve better alignment between IT (information technology) and organizations, a concept is needed to lead to the success of a business. The current market strategy is that marketing strategies have been directly identified as strategic organizational capabilities to create unique differential advantages (Burns et al., 2014). It is very important to recognize the importance of strategic marketing for the long-term success of the company to face increased market competition.

The local marketing strategy is about adjusting and adapting marketing strategies to fit the unique elements of individual markets around the world. Some researchers advocate an approach of adaptation (Thrassou \& Vrontis, 2006). Proponents of adaptation strategies argue that the company is difficult to control climate, topography, consumer tastes, law, culture, race, technology, disposable income, employment, literacy letters and levels of education, taxation, local labor costs, nationalism, and society, among others, which exist in international markets and even between markets in the same country. Adaptation to marketing strategies refers to the company's ability to analyze situations and determine directions to adjust or adjust marketing activities that meet customer needs and market demand (Jirawuttinaunt \& Ussahawanitchakit, 2011).

Tallon (2008) examined alignment at the process level (past research tended to operationalize alignment at the firm level) and found that it was positively correlated with IT business value at the process level. The resulting alignment between IT and business strategy can enable agility since essential changes in business strategy can be easily communicated to IT executives in contrast the potential for IT-led capabilities to redirect business strategy can be shared with business executives. In this way, the path dependencies and routines provided by alignment can enable increased adaptiveness (Zahra \& Geor- ge, 2002; He \& Wong, 2004; Lavie \& Rosenkopf, 2006). This type of collaboration can create a virtuous cycle as they search for new IT and business opportunities create and share new knowledge with suppliers, customers, and critical business partners relationships that are often a necessary part of how firms react to change (Lavie \& Rosenkopf, 2006). From this literature review, this study use alignment between IT with a strategy, which, in case is a marketing adaptation strategy, as an exogenous variable in the research model. Also, the research found the gap between IT alignment and firm performance. Table 1 shows the research gap between IT alignment and firm performance.

Table 1. Research Gap

\begin{tabular}{ll}
\hline Researcher & $\begin{array}{l}\text { IT Alignment à } \\
\text { Firm Performance }\end{array}$ \\
\hline $\begin{array}{l}\text { Palmer and Markus } \\
(2000)\end{array}$ & not correlated \\
$\begin{array}{l}\text { Tallon and Pinson- } \\
\text { neault (2011) }\end{array}$ & $\begin{array}{l}\text { not significantly } \\
\text { negative } \\
\text { Bergeron, Raymond, } \\
\text { and Rivard (2004) }\end{array}$ \\
$\begin{array}{l}\text { Chan, Sabher- } \\
\text { wal, and Thatcher } \\
\text { (2006) }\end{array}$ & significantly positive \\
$\begin{array}{l}\text { Cai, Liu, Huang, and } \\
\text { Liang (2017) } \\
\text { Baum and Wally } \\
\text { (2003) }\end{array}$ & not significant \\
\hline
\end{tabular}

These research gaps are the main reason for this study to provide the right solution by adding mediating variables in the relationship between alignment with company performance, where company performance in this study uses sustainable competitive advantage. Companies that do not have a competitive advantage will be unable to compete with other companies so that performance decreases. This study use agility as mediating variable, where the definition of agility according to several researcher seems to be similar to dynamic abilities (Teece et al., 1997); market orientation (Kohli \& Jaworski, 1990); absorption (Zahra \& George, 2002); strategic flexibility (Grewal \& Tansuhaj, 2001). However, each researcher has different features 
regarding the applicable scope and composition dimensions. Dynamic ability is the ability to integrate, build, and reconstruct resources and the ability of an organization to adapt to changes in the environment. Agility is one of the sub-capabilities of dynamic capabilities. Agility is very valuable, difficult to duplicate, and does not have permanently sustainable capabilities, and this, is related to efforts to detect and exploit opportunities in a dynamic environment. Therefore, agility can contribute to improving organizational performance as a core capability of the organization associated with competitive strategies and performance.

Pekalongan City is known as the center of batik, which has potential in the batik industry and has overgrown. Pekalongan has a lot of potential for small and medium enterprises that can be maximally developed. Batik SME make a significant contribution to economic progress in Pekalongan. Table 2 shows examples of data on batik sales in Pekalongan for the last five years.

Table 2. Data on Batik Sales in Pekalongan

\begin{tabular}{ll}
\hline Year & Sales Value \\
\hline 2015 & $17.384 .060,75$ \\
2016 & $19.081 .546,65$ \\
2017 & $17.683 .268,64$ \\
2018 & $17.233 .356,68$ \\
\hline
\end{tabular}

Sources: Department of Industry, Trade, Cooperatives and SME Pekalongan city (2019)

Based on Table 2, it appears that the volume and value of batik sales in Pekalongan experience uncertain conditions. In 2016, the volume of batik reached IDR 19,081,546,650 and decreased in 2017 to IDR 17,683,268,640. The existence of the Pekalongan batik industry must still be maintained, considering that batik is a characteristic of Indonesian products. Therefore, a strategy for companies engaged in the batik industry to have a strong competitive advantage, because this is a business phenomenon to seek the right solution so that batik sales continue to increase, hence, that it can improve the performance of Batik SME.
The increase or decrease in sales can be caused by several factors, such as changes in competition and consumers so companies need to adjust to ensure survival and success in business performance. The company's ability to produce or create positions in the market is the core of the development strategy. Differentiation enables companies to utilize their competitive advantages fully and hence to achieve high returns (Yeung \& Lau, 2005; Sutapa et al., 2017). To face uncertain competition changes, IT development is needed to support sales. According to a direct interview with Tjandrawati, Head of Pekalongan UMKM, not all of Batik SME in Pekalongan have used IT in their sales. Also, Batik SME in Pekalongan also have not fully implemented the marketing adaptation strategy. Furthermore some of them are not responsive to customers so that many customers end up buying elsewhere, such as Solo, Pati, or Jepara. Also, some of them also have difficulty in allocating resources to meet unique customer demand. Therefore, this study uses IT variables combined with marketing adaptation strategy and agility used to improve competitive advantage.

Based on the research gaps and business phenomena described above, it is interesting to conduct research in Batik UKM in Pekalongan by using IT alignment combined with marketing adaptation strategies to enhance competitive advantage. The following paper aims to investigate the mediating effects of response, operational flexibility, and business relations in the relationship between aligning IT strategies and sustainable competitive advantage. The novelty of this study is that there are still many differences in the results of previous studies that have not found established research results. Thus, it is very important to conduct this research, because the research gap from the results of previous research can be resolved. Furthermore, the results of this study contributed to the development of Batik SMEs in the face of fierce competition in the global market.

\section{Hyphothesis Development Equilateral Agility}

Based on the literature review on agility, this study split the research of agility into three 
Lutfi Nurcholis \& Budhi Cahyono/ The Equilateral Agility Concept as Mediating Variable in Relationship....

categories, namely responsiveness, operational flexibility, and business relationships. From these categories, we develop a new concept, namely, Equilateral Agility. Equilateral Agility is organizational agility based on responsiveness, operational flexibility, and business relationships that have the potential to improve performance. These three categories as mediating variables in the relationship between the alignment between IT-marketing adaptation strategy and sustainable competitive advantage. Summary of agility research in Table 3 shows the development of the three categories of agility.

Table 3. Summary of Agility Research

\section{Marketing Adaptation Strategy}

According to Vrontis et al.(2006), marketing strategy is a means by is a means to achieve company goals. They reflect the best opinions of the company about the most advantageous ways of applying their skills and resources on the market, and they are in the inevitable scope. Looking at the fertilizer industry, large fertilizer companies have tried to use strategic market focus either by creating new brands, targeting specific groups, or purchasing existing brands.

Marketing strategies have been directly identified as strategic organizational capabilities to create unique differential advantages in increasing-

\begin{tabular}{|c|c|c|c|c|c|c|}
\hline $\begin{array}{l}\text { Catego- } \\
\text { ries }\end{array}$ & (Park et al., 2017) & $\begin{array}{l}\text { (Cai et al., } \\
\text { 2017) }\end{array}$ & \multicolumn{2}{|c|}{$\begin{array}{l}\text { (Baškarada \& Ko- } \\
\text { ronios, 2018) }\end{array}$} & \multicolumn{2}{|c|}{$\begin{array}{l}\text { (Zitkiene \& Deksnys, } \\
\text { 2018) }\end{array}$} \\
\hline $\begin{array}{l}\text { Respon- } \\
\text { siveness }\end{array}$ & Sensing agility & $\begin{array}{l}\text { Capability to } \\
\text { sense and respond } \\
\text { effectively to mar- } \\
\text { ket opportunities } \\
\text { and threats }\end{array}$ & \multicolumn{2}{|c|}{$\begin{array}{l}\text { Sensing: the ability } \\
\text { to detect new oppor- } \\
\text { tunities and threats } \\
\text { from the external } \\
\text { environment }\end{array}$} & \multirow{2}{*}{\multicolumn{2}{|c|}{$\begin{array}{l}\text { Sensing capabilities } \\
\text { (awareness, competence) } \\
\text { Response capabilities } \\
\text { (reconfiguration, learning, } \\
\text { coordination, coopera- } \\
\text { tion) } \\
\text { Agile Enablers: } \\
\text { Structure and organization } \\
\text { Processes } \\
\text { Technology } \\
\text { Human resources } \\
\text { Network }\end{array}$}} \\
\hline $\begin{array}{l}\text { Operational } \\
\text { Flexibility }\end{array}$ & $\begin{array}{l}\text { Decision making } \\
\text { agility, and acting } \\
\text { agility }\end{array}$ & & \multicolumn{2}{|c|}{$\begin{array}{l}\text { The ability to create } \\
\text { a new opportunity } \\
\text { within the organiza- } \\
\text { tion, make unbiased } \\
\text { decisions about } \\
\text { strategy }\end{array}$} & & \\
\hline $\begin{array}{l}\text { Business } \\
\text { Relation- } \\
\text { ship }\end{array}$ & & & \multicolumn{4}{|c|}{$\begin{array}{l}\text { Shifting: the ability } \\
\text { to effectively imple- } \\
\text { ment new strategy, } \\
\text { business model, and } \\
\text { capabilities. }\end{array}$} \\
\hline $\begin{array}{l}\text { Catego- } \\
\text { ries }\end{array}$ & $\begin{array}{l}\text { (Nejatian et al., } \\
\text { 2018) }\end{array}$ & $\begin{array}{l}\text { (Khatir \& Mian- } \\
\text { rood, 2016) }\end{array}$ & $\begin{array}{l}\text { (Queiroz et al., } \\
\text { 2018) }\end{array}$ & & $\begin{array}{l}\text { ou et al., } \\
\text { 8) }\end{array}$ & $\begin{array}{l}\text { (Saha et al., } \\
\text { 2019) }\end{array}$ \\
\hline $\begin{array}{l}\text { Respon- } \\
\text { siveness }\end{array}$ & $\begin{array}{l}\text { Adjust customer } \\
\text { satisfaction,customer } \\
\text { retention, product/ } \\
\text { service quality, the } \\
\text { flexibility of sale, and } \\
\text { service system }\end{array}$ & Responsibility & & & $\begin{array}{l}\text { ability to } \\
\text { ct and } \\
\text { ond to } \\
\text { ands } \\
\text { edded in } \\
\text { ne } \\
\text { omer } \\
\text { ews }\end{array}$ & $\begin{array}{l}\text { Sensing } \\
\text { Agility } \\
\text { Adaptability }\end{array}$ \\
\hline $\begin{array}{l}\text { Operational } \\
\text { Flexibility }\end{array}$ & $\begin{array}{l}\text { Optimizing human } \\
\text { resource planning and } \\
\text { maintaining system. } \\
\text { Increasing efficiency } \\
\text { R \& D-innovation }\end{array}$ & $\begin{array}{l}\text { Flexibility } \\
\text { Competence }\end{array}$ & $\begin{array}{l}\text { The ability to } \\
\text { respond to } \\
\text { opportunities } \\
\text { and threats } \\
\text { with ease, } \\
\text { speed, and skill }\end{array}$ & & & $\begin{array}{l}\text { Decision- } \\
\text { making } \\
\text { agility } \\
\text { Speed } \\
\text { Flexibility } \\
\text { Capability }\end{array}$ \\
\hline
\end{tabular}


ly competitive markets. It is essential to recognize the importance of strategic marketing for the longterm success of the company (Burns et al., 2014). One element of strategic marketing is the target marketing strategy. To execute target marketing, we must analyze market segmentation (Stern \& Hammond, 2004). Intelligence in market segmentation offers a variety of potential and relevant benefits for organizations in terms of market leadership, strategic positioning, and progress.

Yusof and Aziz (2008) explain that in the strategic adaptation literature, there are at least three schools of thought that have developed over time, which emphasize various dominant factors, that influence the organization's strategic adaptation. The first school of thought emphasizes the primary role of the environment. The second school of thought is a resource-based view (RBV), which explains the success of different companies by investigating the company's internal factors. The third school of thought is an integrative view. Adaptation strategies reflect the company's ability to calculate assumptions about environmental changes and formulate strategy for new conditions, namely, policy to adjust to low costs or differentiation, to accept new approaches, and use integrated approach (Tantong et al., 2010).

A company's ability to analyze situations and determine the direction in implementing new service strategies through a search process for customer needs and desires, market demand, competitor analysis, and intention to develop or produce new methods for creating services
(Nurcholis, 2018). Therefore, organizations must adapt and respond to change by improving or creating new ideas to the market to find new opportunities and achieve success.

Marketing adaptation strategy refers to the company's ability to analyze situations and determine directions to adjust marketing activities that meet customer needs and market demand (Jirawuttinaunt \& Ussahawanitchakit, 2011).

\section{Effects of IT-Strategy Alignment on Perfor- mance/Sustainable Competitive Advantage}

Adjustment improve performance in general (Chan et al., 2001; Bergeron et al., 2004; Kearns \& Sabherwal, 2006; Oh \& Pinsonneault 2007) and in critical areas such as market growth, financial performance, innovation, and reputation (Chan et al., 1997), growth and income (Croteau \& Bergeron, 2001), and cost control (Oh \& Pinsonneault, 2007). Alignment at the process level (past research tended to operationalize alignment at the firm level) and found that it was positively correlated with IT business value at the process level (Tallon, 2008). The primary locus of alignment within the firm (the process where arrangement is highest) varies based on differences in strategic and so arrangement is rarely the same in any two firms.

Table 4 shows the research on the effect of alignment on performance. From this exploration, this study develop hypothesis as follows: H1: IT-strategy alignment significantly affects sustainable competitive advantage.

Table 4. Research on the Effect of Alignment on Performance

\begin{tabular}{ll}
\hline Study & Alignment-Performance \\
\hline Jonathan and Lynne (2000) & Alignment can not improve firm performance \\
Croteau and Bergeron (2001) & IT-infrastructure alignment predicts firm performance \\
Sabherwal and Chan (2001) & Arrangement leads to higher performance in all firms \\
Kearns and Sabherwal (2006) & IT plan is consistent with the use of IT for competitive advantage \\
Bergeron, Raymond, and Rivard (2004) & Alignment is positively related to firm performance \\
Chan, Sabherwal, and Thatcher (2006) & Alignment is positively associated with return for all firms \\
Oh and Pinsonneault (2007) & Adjustment is associated with lower costs, higher sales \& profit \\
Tallon (2008) & Adjustment is associated with higher IT business value for firms \\
\hline
\end{tabular}


Lutfi Nurcholis \& Budhi Cahyono/ The Equilateral Agility Concept as Mediating Variable in Relationship....

\section{Effect of IT-Strategy Alignment on Agility}

Much of the literature has emphasized response capabilities, which, while necessary and essential, are not the only predictor of coordination. Thus, Ghasemaghaei et al. (2017) find that the use of data analytics is only useful to coordination as firms master the fit between their data analytics tools, data, people, and tasks. The business value from digital data streams and business analytic applications can improve agility in resource allocation processes (Anand et al., 2016). Similarly, business intelligence technology, in isolation, is less predictive of sensing, decision-making, and acting agility than combination between technology with environmental and organizational factors (Park et al., 2017). One research about how digital platform technologies relate to agility was conducted by (Ravichandran, 2018).

Digital platforms are a means to build integrated systems from commoditized IT components that can quickly scale and adapt to meet a diverse range of business needs ( $\mathrm{Ti}$ wana et al., 2010; Richardson et al., 2018). IT platforms reduce the cost of application sharing by allowing IT architects to create new ways for component modules to work together. Modular systems have enabled distributed innovation to occur in a digital ecosystem. Ecosystems can encompass individuals, corporations, and communities that are individually autonomous but connected through an underlying technical system. Ecosystems explain why digital initiatives fail even when a firm can deliver critical projects to scope, on time, and budget. In any ecosystem, agility is shaped not just by what the focal firm does but by what it ecosystem peers are doing (Tsatsou et al., 2010).

Cloud technology has also received attention intending to offer flexible IT infrastructure. For example, in an era where organizations are increasingly using a cloud-first approach to IT infrastructure, Gill et al. (2014) show how different divisions of the Australian government are using the cloud to transform their operations and, thus, improve their agility. As new IT innovation allows users to perform detailed data analysis (Hani et al., 2017) find that for a Norwegian digital marketplace, self-service business intelligence helps market capitalizing agility (faster insights into market participants) and operational adjustment agility (changes to organization structure, employee empowerment, equal access to data, and opportunities for data access).

Self-service business intelligence (BI) is an approach to data analytics that enables business users to access and work with corporate data even if they do not have a background in statistical analysis, business intelligence, or data mining. Self-service BI tools allow users to filter, sort, analyze, and visualize data without involving the organization's business intelligence and IT teams. With traditional BI tools, data scientists and IT teams control access to data. Users requesting new reports and dashboard submit a list of business requirements; once the project is approved, which can take weeks, the data is extracted, transformed, and loaded into an operational data warehouse.

The IT or business intelligence team then produces the report or dashboard. Conversely, a self-service business intelligence architecture is used by people who may not be technology savvy; therefore, it is imperative that the user interface for self-service analytics software be intuitive. User-friendly dashboards and navigation should address the needs of both casual users (those who may need to access data but not generate reports) and power users (more savvy users, responsible for not just accessing, and analyzing the data, but also ad hoc reporting). Ideally, training should be provided to help users understand what data is available and how that information can be queried to make data-driven decisions to solve business problems. Hence, the refinement stage of the literature shows how IT innovation has altered the dynamics of organizational agility, not just in how IT can deliver better, faster, and cheaper ways to sense change but in how IT can enable the locus of agility to transition from the organizational level to a process or user level. 
Table 5. Summary of Publications on IT and Agility

\begin{tabular}{ll}
\hline Study & IT-Agility \\
\hline Van Oosterhout et al. (2006) & IT can be both an enabler and disabler of agility. While in the face of un- \\
& predictable changes, integrated IS architecture enables agility. \\
Tiwana et al. (2010) & IT architecture modularity correlated with IT agility. \\
Lu and Ramamurthy (2011) & IT capability has a positive effect on operational adjustment agility. \\
Tallon and Pinsonneault (2011) & Strategic IT alignment has a positive effect on agility. \\
Ngai et al. (2011) & IT competence support supply chain agility for competition. Based on \\
& the knowledge literature, IT competence is defined as the set of IT-related \\
& knowledge and experience that a business manager possesses (Bassellier, \\
& Benbasat, \& Reich, 2003). \\
Bradley et al. (2012) & IT alignment and IT operational effectiveness enhance coordination. \\
Nazir and Pinsonneault (2012) & IT applications electronic integration leads to sensing and responding \\
& capabilities. \\
Roberts and Grover (2012) & IT infrastructure capabilities facilitate agility. \\
Chakravarty et al. (2013) & IT competencies enhance agility. \\
Huang et al. (2014) & Information processing capability enables operational agility. \\
Richardson et al. (2018) & A social enterprise's IT platform and related digital options affect customer, \\
& partnering and operational agility. \\
Chen et al. (2014) & IT capability enhances agility. \\
Lee et al. (2015) & IT ambidexterity has a positive effect on readiness. \\
Tiwana and Kim (2015) & IT governance enhances IT strategic agility. \\
Lowry and Wilson (2016) & IT agility is positively influenced by both IT service quality. \\
Park et al. (2017) & IT affects agility is embedded in a configuration of organizational. \\
Queiroz et al. (2018) & IT application orchestration affect process agility. \\
Ravichandran (2018) & Digital platforms enhance readiness. \\
Fink and Neumann (2018) & IT infrastructure capabilities affect strategic agility. \\
Zhou et al. (2018) & Online customer review affects customer agility. \\
\hline
\end{tabular}

Table 5 shows the summary of previous research on the impact of IT on organizational agility. Based on the summary in Table 5, this study develop hypotheses as follows:

H2: IT-strategy alignment significantly affects responsiveness.

H3: IT-strategy alignment significantly affects operational flexibility.

H4: IT-strategy alignment significantly affects the business relationship.

\section{Effect of Agility on SCA/Performance}

Agility can improve performance by expanding a firm's repertoire of competitive actions and the nature of its possible responses to envi- ronmental change (Sambamurthy et al., 2003). As argued in the literature on real options, agility gives firms the opportunity to respond to change and to engage in other actions that control market risk and uncertainty (Benaroch et al., 2006). Agile firms can, therefore, have a wide array of market-response options. Having options in the form of flexible IT infrastructure, a flexible organizational structure, or slack resources allows the firm to be innovative, and to actively respond to new market opportunities as they occur (Nohria \& Gulati, 1996). Firms that exercise these options can expect some future benefits in the form of revenues or profitability, cost avoidance, or higher market growth. Accordingly, when firms are bet- 
Lutfi Nurcholis \& Budhi Cahyono/ The Equilateral Agility Concept as Mediating Variable in Relationship....

Table 6. Research on the Effect of Agility on SCA / Performance

\begin{tabular}{ll}
\hline Study & Agility-SCA/Performance \\
\hline Judge and Miller (1991) & Decision speed significantly affect sales growth and profitability. \\
Teece et al. (1997) & Strategic flexibility generates competitive advantage. \\
Adler et al. (1999) & Meta routines increase performance and efficiency. \\
Young-Ybarra and Wiersema (1999) & Increased competitiveness acquired through strategic flexibility. \\
Grewal and Tansuhaj (2001) & Strategic flexibility positively influences firm performance. \\
Worren et al. (2002) & Strategic flexibility is positively associated with firm performance. \\
Joshi and Sharma (2004) & Strategic flexibility is related to new product performance. \\
Nadkarni and Narayanan (2007) & Strategic flexibility significantly affects firm performance. \\
Tallon and Pinsonneault (2011) & Agility significantly affects firm performance (ROA, net margin, and \\
& operating income/assets). \\
Santos-Vijande (2012) & Higher flexibility can increase competitive advantage. \\
Ravichandran (2018) & Organizational agility significantly affects firm performance. \\
\hline
\end{tabular}

ter able to react to changes in product demand, to increase the pace of innovation, or to expand into new markets, they are more likely to experience higher profit, reduced costs, and improved market share at a later point in time (Sambamurthy et al., 2003). Table 6 shows the summary of previous research on the effect of agility on SCA/ Performance.

From the literature review above, this study develop hypothesis as follows:

H5: Responsiveness significantly affects sustainable competitive advantage.

H6: Operational flexibility significantly affects sustainable competitive advantage.

H7: Business relationship significantly affects sustainable competitive advantage.

\section{METHOD}

\section{Sample}

This research involves several constructs that have been put forward in the design of hypotheses. These constructs exist that serve as exogenous variables are IT-strategy alignment. For endogenous variables consisting of responsiveness, operational flexibility, business relationship, and sustainable competitive advantage. Data collection techniques used in this study is a type of purposive sampling method. The population used are all batik SME in Pekalongan. The criteria used in the sampling requirements in this study are batik SME that have been operating for a minimum of 10 years and have a minimum of 25 employees. Respondents are 270 managers or Batik SME owners in Pekalongan. Data collection through face-to-face interviews and questionnaires was conducted. Questionnaires collected and filled as much as 199 of the total respondents, because the other respondents do not want to interview directly because they are busy and have limited time During data processing, there are still 10 data that are inappropriate to use because it is not filled in completely. The total sample of this study was 189 respondents or $70 \%$ of the total respondents selected. This sample size has met the criteria of at least 100 respondents to be processed with the AMOS SEM program (Ferdinand, 2002).

\section{Measurements}

The indicator of responsiveness consisting four indicators includes: responsiveness to changes in demand, innovation, service and pricing. The indicators of operational flexibility are response times to new product launches by rivals, market expansion, and changes in product mix. The indicator of business relationship is developing closer links with suppliers, monitoring product and service quality, monitoring delivery times (Sambamurthy et al., 2003). The indicator of IT-strategy alignment includes: utilizing information technology media for new market 
Table 7. Regression Weights of Indicator Variables

\begin{tabular}{|c|c|c|c|c|c|c|c|}
\hline & & & Estimate & S.E. & C.R. & $\mathbf{P}$ & Label \\
\hline AIT1 & $<---$ & AIT & 1.000 & & & & \\
\hline AIT2 & $<---$ & AIT & .662 & .096 & 6.863 & $* * *$ & par_7 \\
\hline AIT3 & $<---$ & AIT & 1.193 & .145 & 8.218 & $* * *$ & par_8 \\
\hline EQA2 & $<--$ & EQA & 1.032 & .165 & 6.260 & $* * *$ & par_9 \\
\hline EQA3 & $<---$ & EQA & 1.205 & .187 & 6.440 & $* * *$ & par_10 \\
\hline EQB3 & $<---$ & $\mathrm{EQB}$ & 1.000 & & & & \\
\hline EQB2 & $<---$ & $\mathrm{EQB}$ & .922 & .134 & 6.898 & $* * *$ & par_11 \\
\hline EQB1 & $<--$ & $\mathrm{EQB}$ & 1.063 & .150 & 7.091 & $* * *$ & par_12 \\
\hline SCA3 & $<--$ & SCA & 1.000 & & & & \\
\hline SCA2 & $<--$ & SCA & .675 & .081 & 8.377 & $* * *$ & par_13 \\
\hline SCA1 & $<---$ & SCA & .810 & .096 & 8.453 & $* * *$ & par_14 \\
\hline EQC3 & $<--$ & EQC & 1.000 & & & & \\
\hline EQC2 & $<---$ & EQC & .973 & .168 & 5.780 & $* * *$ & par_15 \\
\hline EQC1 & $<--$ & EQC & 1.134 & .203 & 5.592 & $* * *$ & par_16 \\
\hline EQA4 & $<---$ & EQA & .693 & .149 & 4.643 & $* * *$ & par_18 \\
\hline EQA1 & $<--$ & EQA & 1.000 & & & & \\
\hline
\end{tabular}

exploration, marketing program development, and product diversity (Jirawuttinaunt \& Ussahawanitchakit, 2011). The indicator sustainable competitive advantage includes: have unique products, durability and have strategic assets different from competitors (Barney, 1991).

This study using content validity to test the validity of the questionnaire, in a way that the initial survey was first reviewed by asking experts' opinions in the field of SME about their order and range of response options, the number of questions, and how to express them. After know about people's opinions, the surveyor distributing the questionnaires among a number of SME, and ask to express their ideas about the sentences in the survey. This study formulating the final questionnaire after several stages of review and a pilot phase. This study also ranking all constructs of a 10-point Likert scale from "strongly disagree" (1) to "strongly agree" (10). To test the construct of the questionnaire validity, the ones whose results verified the validity of the questionnaire construct by confirmatory factor analysis. The research has used Regression Weights to determine the questionnaire reliability. Table 7 shows the result of regression weights from AMOS. All indicator variables significant because they have C.R. value $>2$.

\section{RESULT AND DISCUSSION}

The empirical model test is using Structural Equation Modeling. The model indicates that Chi-square $=141.047$ with probability value of 0.002; RMSEA $=0.049$; GFI $=0.914$; AGFI $=0.879$; $\mathrm{CMIN} / \mathrm{DF}=1.454$; TLI=0.932; and $\mathrm{CFI}=0.945$. Based on this value, the result of the model is a fit (Table 8). Based on statistically analyzing the results of this study, it indicates conformity with the required standard values. Table 8 shows that all parameters meet the cut of value criteria.

Table 8. The Goodness of Fit Index

\begin{tabular}{|c|c|c|c|}
\hline Parameter & Result & $\begin{array}{l}\text { Cut off } \\
\text { value }\end{array}$ & $\begin{array}{l}\text { Expla - } \\
\text { nation }\end{array}$ \\
\hline $\begin{array}{l}\text { Chi-Square } \\
(\mathrm{df}=97)\end{array}$ & 141.047 & $<145.789$ & Good \\
\hline Probability & .002 & $\geq .05$ & Good \\
\hline RMSEA & .049 & $\leq .08$ & Good \\
\hline GFI & .914 & $\geq .90$ & Good \\
\hline AGFI & .879 & $\geq .90$ & Marginal \\
\hline CMIN/DF & 1.454 & $\leq 2.00$ & Good \\
\hline TLI & .932 & $\geq .95$ & Good \\
\hline CFI & .945 & $\geq .95$ & Good \\
\hline
\end{tabular}


Lutfi Nurcholis \& Budhi Cahyono/ The Equilateral Agility Concept as Mediating Variable in Relationship....

Table 9. Regression Weight of Variables

\begin{tabular}{|c|c|c|c|c|c|c|c|}
\hline & & & Estimate & S.E. & C.R. & $\mathbf{P}$ & Label \\
\hline EQA & $<--$ & $\mathrm{AIT}$ & .299 & .078 & 3.843 & $* * *$ & par_1 \\
\hline $\mathrm{EQB}$ & $<---$ & $\mathrm{AIT}$ & .063 & .088 & .716 & .474 & par_3 \\
\hline EQC & $<---$ & AIT & .103 & .076 & 1.352 & .176 & par_5 \\
\hline SCA & $<--$ & $\mathrm{AIT}$ & .039 & .096 & .403 & .687 & par_6 \\
\hline SCA & $<---$ & EQA & .274 & .133 & 2.059 & .039 & par_2 \\
\hline SCA & $<---$ & $\mathrm{EQB}$ & .495 & .104 & 4.755 & $* * *$ & par_4 \\
\hline SCA & $<---$ & EQC & .342 & .118 & 2.888 & .004 & par_17 \\
\hline
\end{tabular}

Table 9 shows that from the seven hypotheses, empirical data does not support three hypotheses, because not influence significantly (C.R. $<2)$, and four hypotheses were have significant influence (C.R.> 2). The hypothesis of IT-strategy alignment affects substantially responsiveness. The premise of IT-strategy alignment does not affect substantially operational flexibility. The interpretation of IT-strategy alignment does not affect substantially the business relationships. The prediction of responsiveness, operational flexibility, and business relationship significantly affect sustainable competitive advantage. The premise of IT-strategy alignment does not considerably affect sustainable competitive advantage.

\section{Direct and Indirect Effect}

Table 10 and Table 11 show that indirect value effect between AIT and SCA larger than the direct impact between AIT and SCA (0.139 $>0.036)$. This means that responsiveness, operational flexibility, and business relationship mediate correlation between IT-strategy alignment and a sustainable competitive advantage.

Table 10. Direct Effect

\begin{tabular}{cccccc}
\hline & AIT & EQC & EQB & EQA & SCA \\
\hline EQC & .127 & .000 & .000 & .000 & .000 \\
EQB & .066 & .000 & .000 & .000 & .000 \\
EQA & .389 & .000 & .000 & .000 & .000 \\
SCA & .036 & .259 & .443 & .197 & .000 \\
\hline
\end{tabular}

Table 11. Indirect Effect

\begin{tabular}{lccccc}
\hline & AIT & EQC & EQB & EQA & SCA \\
\hline EQC & .000 & .000 & .000 & .000 & .000 \\
EQB & .000 & .000 & .000 & .000 & .000 \\
EQA & .000 & .000 & .000 & .000 & .000 \\
SCA & .139 & .000 & .000 & .000 & .000 \\
\hline
\end{tabular}

The hypothesis of IT-strategy alignment significantly affects responsiveness. The increase of IT-strategy alignment will also increase responsiveness. Batik SME can utilize information technology for exploring new market, developing marketing program, and product diversity to changes in demand, innovation, service, and pricing. The result of this study support the previous research which states that smart business network structure improves agility (Vervest et al., 2004), creating a digital option platform can enable companies to feel and respond to rapidly changing market conditions (Overby et al., 2006), the application of IT electronic integration leads to responsiveness (Nazir \& Pinsonneault, 2012), IT enables business functions when combined with complementary coordination mechanisms, allowing the companies to quickly respond to customer-based opportunities (Roberts \& Grover, 2012), online customer review volume has relationship with customer agility (Zhou et al., 2018).

The hypothesis of IT-strategy alignment does not significantly affect operational flexibility. The increase of IT-strategy align- 
Figure 1 shows the result of the Full Model Analysis.
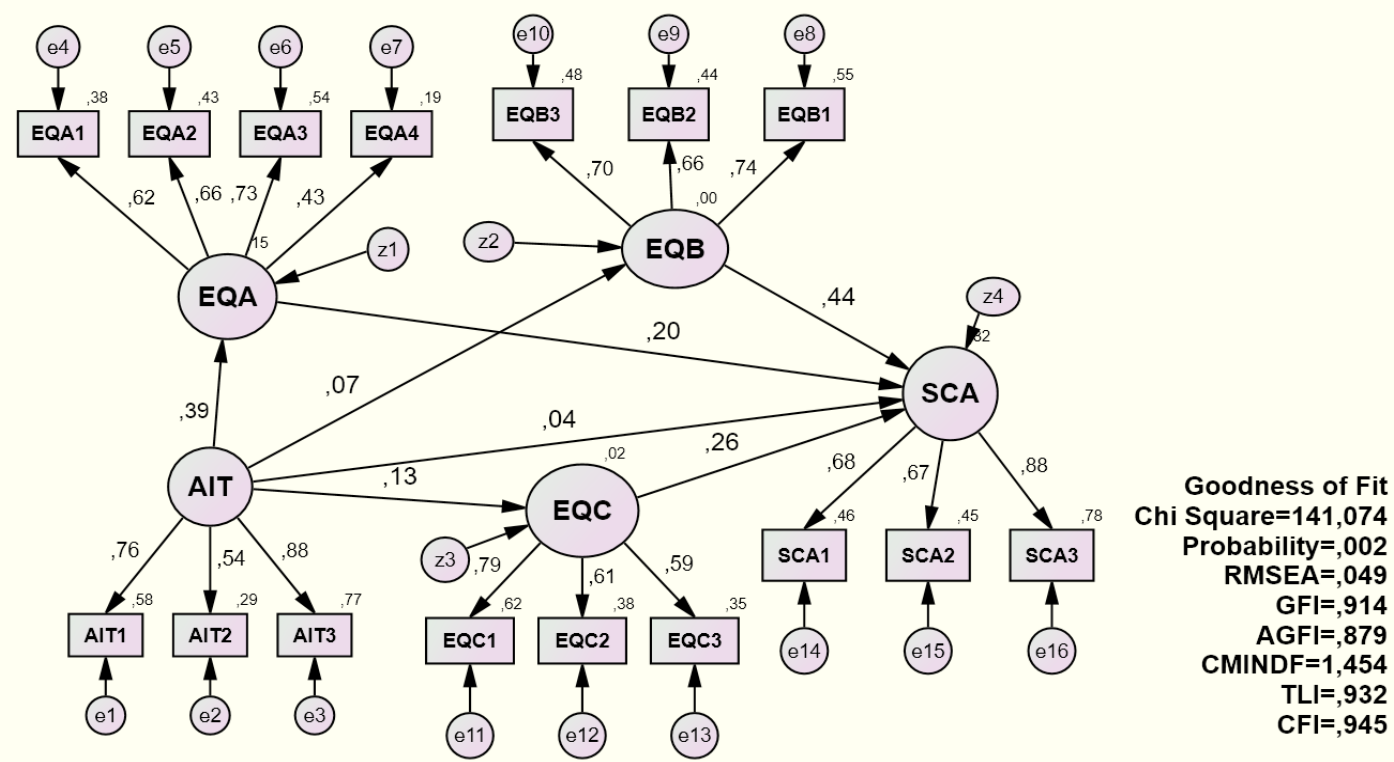

Figure 1. The Results of Full Model Analysis

ment will not increase operational flexibility. Batik SME cannot accelerate response times to new product launches by rivals, market expansion, and changes in product mix with utilizing information technology for further market exploration, marketing program development, and product diversity. The result of this study does not support the previous research which states that IT-supported information processing networks enable operational agility (Huang et al., 2014), social enterprise's IT platforms and related digital options affect operational agility (Richardson et al., 2018), IT capabilities has an effect positive on agility of operational adjustments ( $\mathrm{Lu} \&$ Ramamurthy, 2011), IT enables business functions enabling companies to quickly respond to customer-based opportunities (Roberts \& Grover, 2012).

The hypothesis of IT-strategy alignment does not significantly affect the business relationships. The increase of IT-strategy alignment will not increase business relationships. Batik SME cannot develop closer links with suppliers, monitoring product and service quality, monitoring delivery times with utili- zing information technology for new market exploration, marketing program development, and product diversity, because not all Batik SME in Pekalongan use IT fully. They are using IT only for sell their product, not for develop closer links with suppliers, monitoring product and service quality, and monitoring delivery times. The result of this study does not support the previous research which stated that the development of IT-supported information processing networks enable operational agility (Huang et al., 2014), the application of information, and communication technology increases labor agility (Breu et al., 2002).

The hypothesis of responsiveness, operational flexibility, and business relationship significantly affect sustainable competitive advantage. The increase of responsiveness, operational flexibility, and business relationship will trigger the rise of sustainable competitive advantage. Batik SME can have unique product, durability and have strategic assets different from competitors if responsive to changes in demand, innovation, service, and pricing, accelerate response times to new pro- 
Lutfi Nurcholis \& Budhi Cahyono/ The Equilateral Agility Concept as Mediating Variable in Relationship....

duct launches by rivals, market expansion and changes in product mix, developing closer links with suppliers, monitoring product and service quality and monitoring delivery times. The result of this study support the previous research which stated that speed decisions significantly affect sales growth and profitability (Judge \& Miller, 1991); strategic flexibility results in competitive advantage (Teece et al., 1997); higher flexibility can increase competitive advantage (Santos-Vijande et al., 2012); increased competitiveness gained through strategic flexibility (Young-Ybarra \& Wiersema, 1999); strategic flexibility positively influences company performance (Grewal \& Tansuhaj, 2001); strategic flexibility is positively related to company performance (Worren et al., 2002); strategic flexibility is related to the production of new products (Joshi \& Sharma, 2004); strategic flexibility has a significant positive effect on company performance (Nadkarni \& Narayanan, 2007); and agility has a positive and considerable influence on company performance (ROA, net margin, and operating income/assets) (Tallon \& Pinsonneault, 2011).

The hypothesis of IT-strategy alignment does not significantly affect sustainable competitive advantage. The increase of IT-strategy alignment will not trigger the rise of sustainable competitive advantage. Batik SME cannot have unique product, durability, and have strategic assets different from competitors with utilizing information technology for new market exploration, marketing program development, and product diversity, because not all Batik SME in Pekalongan use IT fully. They are using IT only for sell their product, not for develop unique product and strategic assets different from competitors. The result of this study does not support the previous finding of research which stated that IT alignment could improve performance/ sustainable competitive advantage (Zahra \& Covin, 1993; Croteau \& Bergeron, 2001; Bergeron et al., 2004; Kearns \& Sabherwal, 2006; Oh \& Pinsonneault, 2007).
Responsiveness, operational flexibility, and business relationship mediate correlation between IT-strategy alignment and the sustainable competitive advantage. IT-strategy alignment can indirectly affect sustainable competitive advantage through responsiveness, operational flexibility, and business relationship. The sustainable competitive advantage of the Batik SME can improve through IT-strategy alignment with responsiveness, operational flexibility, and business relationship. The result of this study supports the previous finding of research, which stated that adjustment mediates the effect of alignment on company performance (Bradley et al., 2012).

\section{CONCLUSION AND RECOMMENDATION}

The result shows the importance of responsiveness, operational flexibility, and business relationship to improve sustainable competitive advantage of Batik SME in Pekalongan. Responsiveness, operational flexibility and business relationship have the confidence and value that puts customers on every business decision. It encourages the $\mathrm{Ba}$ tik SME to improve the sustainable competitive advantage based on the customers' expectations. IT-strategy alignment is essential to enhance responsiveness, operational flexibility, and business to gain the sustainable competitive advantage.

In managerial implication, IT-strategy alignment can improve the sustainable competitive advantage of the Batik SME. IT-strategy alignment in marketing policy can be done by utilizing information technology for new market exploration, marketing program development, and product diversity. Responsiveness, operational flexibility, and business relationship are needed by Batik SME to improve sustainable competitive advantage according to IT-strategy alignment. Improving IT-strategy alignment can gain responsiveness, operational flexibility, and business relationship. Improving responsiveness, operational flexibility, and business 
relationship can gain a sustainable competitive advantage.

The theoretical implication of this research is that develop IT-strategy alignment, responsiveness, operational flexibility, and business relationship simultaneously can improve the sustainable competitive advantage of Batik SME. The role of IT-strategy alignment in improving sustainable competitive advantage will be more effective if it is done indirectly through responsiveness, operational flexibility, and business relationship. This implication in line with dynamics capability theory, resource-based view, and information processing theory.

The finding of this study contribute to the development of science, especially management science. The limitation of this research focuses only on the Batik SME with relatively small sample size and does not separate the scale of micro, small, and medium enterprises. Leaders or managers of Batik SME have different abilities in developing their business. They also have different views and behaviors towards the willingness to learn and understand market changes. Result of this study shows that three hypotheses was not accepted. An interesting area to other research with different respondents or variables. Future research also can be applied to the business sector with a larger scale and broader geographical area.

\section{REFERENCES}

Adler, P. S., Goldoftas, B., \& Levine, D. I. (1999). Flexibility Versus Efficiency? a Case Study of Model Changeovers in the Toyota Production System. Organization Science, 10(1), 4368.

Anand, A., Coltman, T., \& Sharma, R. (2016). Four Steps to Realizing Business Value from Digital Data Streams. MIS Quarterly Executive, 15(4), 259-277.

Barney, J. (1991). Firm Resources and Sustained Competitive Advantage. Journal of Management, 17(1), 99-120.

Baškarada, S., \& Koronios, A. (2018). The 5S Or- ganizational Agility Framework: a Dynamic Capabilities Perspective. International Journal of Organizational Analysis, 26(2), 331342.

Bassellier, G., Benbasat, I., \& Reich, B. H. (2003). The Influence of Business Managers' IT Competence on Championing IT. Information Systems Research, 14(4), 317-336.

Baum, J. R., \& Wally, S. (2003). Strategic Decision Speed and Firm Performance. Strategic Management Journal, 24(11), 1107-1129.

Benaroch, M., Lichtenstein, Y., \& Robinson, K. (2006). Real Options in Information Technology Risk Management: an Empirical Validation of Risk-Option Relationships. MIS Quarterly: Management Information Systems, 30(4), 827-864.

Bergeron, F., Raymond, L., \& Rivard, S. (2004). Ideal Patterns of Strategic Alignment and Business Performance. Information and Management, 41(8), 1003-1020.

Bradley, R. V., Pratt, R. M. E., Byrd, T. A., Outlay, C. N., \& Wynn, D. E. (2012). Enterprise Architecture, IT Effectiveness and the Mediating Role of IT Alignment in US Hospitals. Information Systems Journal, 22(2), 97-127.

Breu, K., Hemingway, C. J., Strathern, M., \& Bridger, D. (2002). Workforce Agility: the New Employee Strategy for the Knowledge Economy. Journal of Information Technology, 17(1), 2131.

Burns, A. C., Bush, R. F., \& Sinha, N. (2014). Marketing Research (Vol. 7). Harlow: Pearson.

Cai, Z., Liu, H., Huang, Q. \& Liang, L. (2017). Developing Organizational Agility in Product Innovation: the Roles of IT Capability, KM Capability, and Innovative Climate. R $\backsim D$ Management, 49(4), 421-438

Chakravarty, A., Grewal, R., \& Sambamurthy, V. (2013). Information Technology Competencies, Organizational Agility, and Firm Performance: Enabling and Facilitating Roles. Information Systems Research, 24(4), 976-997.

Chan, Y. E., Huff, S. L., Barclay, D. W., \& Copeland, D. G. (1997). Business Strategic Orientation, Information Systems Strategic Orientation, and Strategic Alignment. Information Systems Research, 8(2), 125-150.

Chan, Y. E., Sabherwal, R., \& Thatcher, J. B. (2006). Antecedents and Outcomes of Strategic IS 
Lutfi Nurcholis \& Budhi Cahyono/ The Equilateral Agility Concept as Mediating Variable in Relationship....

Alignment: an Empirical Investigation. IEEE Transactions on Engineering Management, 53(1), 27-47.

Chen, Y., Wang, Y., Nevo, S., Jin, J., Wang, L., \& Chow, W. S. (2014). IT Capability and Organizational Performance: the Roles of Business Process Agility and Environmental Factors. European Journal of Information Systems, 23(3), 326-342.

Croteau, A.-M., \& Bergeron, F. (2001). An Information Technology Trilogy: Business Strategy, Technological Deployment and Organizational Performance. The Journal of Strategic Information Systems, 10(2), 77-99.

Ferdinand, A. (2002). Structural Equation Modeling in Management Research. UNDIP Press: Semarang.

Fink, L., \& Neumann, S. (2018). Gaining Agility through IT Personnel Capabilities: the Mediating Role of IT Infrastructure Capabilities. Journal of the Association for Information Systems, 8(8), 440-462.

Ghasemaghaei, M., Hassanein, K., \& Turel, O. (2017). Increasing Firm Agility through the Use of Data Analytics: the Role of Fit. Decision Support Systems, 101(9), 95-105.

Gill, A. Q. Smith, S., Beydoun, G., \& Sugumaran, V. (2014). Agile Enterprise Architecture: a Case of a Cloud Technology-Enabled Government Enterprise Transformation. Proceedings. Pacific Asia Conference on Information Systems, PACIS 2014, January.

Grewal, R., \& Tansuhaj, P. (2001). Building Organizational Capabilities for Managing Economic Crisis: the Role of Market Orientation and Strategic Flexibility. Journal of Marketing, 65(2), 67-80.

Hani, I. B., Deniz, S., \& Carlsson, S. A. (2017). Enabling Organizational Agility through SelfService Business Intelligence: the Case of a Digital Marketplace. Proceedings. 21st Pacific Asia Conference on Information Systems (PACIS). Malaysia.

He, Z. L., \& Wong, P.-K. (2004). Exploration vs. Exploitation: an Empirical Test of the Ambidexterity Hypothesis. Organization Science, 15(4), 481-494.

Huang, P.-Y. Y., Pan, S. L., \& Ouyang, T. H. (2014). Developing Information Processing Capability for Operational Agility: Implications from a Chinese Manufacturer. European
Journal of Information Systems, 23(4), 462480.

Jirawuttinaunt, S., \& Ussahawanitchakit, P. (2011). Effects of Marketing Adaptation Strategy on Customer Response, Marketing Excellence and Marketing Performance of Food Product Business in Thailand. IJBS 11(1), 1-16.

Joshi, A. W., \& Sharma, S. (2004). Customer Knowledge Development: Antecedents and Impact on New Product Performance. Journal of Marketing, 68(4), 47-59.

Judge, W. Q. \& Miller, A. (1991). Antecedents and Outcomes of Decision Speed in Different Environmental Contexts. The Academy of Management Journal, 34(2), 449-463.

Kearns, G. S., \& Sabherwal, R. (2006). Strategic Alignment between Business and Information Technology: a Knowledge-Based View of Behaviors, Outcome, and Consequences. Journal of Management Information Systems, 23(3), 129-162.

Khatir, V., \& Mianrood, B. (2016). Comparative Study of Factors Affecting Organizational. Agility in Iran. Proceeding. International Congress on Technology-Engineering and Science, 09-10 Februari, Kuala Lumpur, Malaysia.

Kohli, A. K., \& Jaworski, B. J. (1990). Market Orientation: the Construct, Research Propositions, and Managerial Implications. Journal of Marketing, 54(2), 1-18.

Lavie, D., \& Rosenkopf, L. (2006). Balancing Exploration and Exploitation in Alliance Formation. Academy of Management Journal, 49(4), 797-818.

Lee, O. K., Sambamurthy, V., Lim, K. H., \& Wei, K. K. (2015). How does IT Ambidexterity Impact Organizational Agility? Information Systems Research, 26(2), 398-417.

Lowry, P. B., \& Wilson, D. (2016). Creating Agile Organizations through IT: the Influence of Internal IT Service Perceptions on IT Service Quality and IT Agility. The Journal of Strategic Information Systems, 25(3), 211226.

Lu, Y., \& Ramamurthy, K. (2011). Understanding the Link between Information Technology Capability and Organizational Agility: an Empirical Examination. MIS Quarterly, 35(4), 931-954.

Nadkarni, S., \& Narayanan, V. K. (2007). Strategic 
Schemas, Strategic Flexibility, and Firm Performance: the Moderating Role of Industry Clockspeed. Strategic Management Journal, 28(3), 243-270.

Nazir, S., \& Pinsonneault, A. (2012). Journal of the Association for Information IT and Firm Agility: an Electronic Integration Perspective IT and Firm Agility: an Electronic Integration. Journal of the Association for Information Systems, 13(3), 150-171.

Nejatian, M., Zarei, M. H., Nejati, M., \& Zanjirchi, S. M. (2018). A Hybrid Approach to Achieve Organizational Agility. Benchmarking: an International Journal, 25(1), 201-234.

Ngai, E. W. T., Chau, D. C. K., \& Chan, T. L. A. (2011). Information Technology, Operational, and Management Competencies for Supply Chain Agility: Findings Fom Case Studies. The Journal of Strategic Information Systems, 20(3), 232-249.

Nohria, N., \& Gulati, R. (1996). Is Slack Good or Bad for Innovation?. Academy of Management Journal, 39(5), 1245-1264.

Nurcholis, L. (2018). Effect of Marketing Strategy Adaptation on Knowledge Exploitability. Jurnal Aplikasi Manajemen, 16(3), 432-439.

Oh, W., \& Pinsonneault, A. (2007). On the Assessment of the Strategic Value of Information Technologies: Conceptual and Analytical Approaches. MIS Quarterly, 31(2), 239-265.

Overby, E., Bharadwaj, A., \& Sambamurthy, V. (2006). Enterprise Agility and the Enabling Role of Information Technology. European Journal of Information Systems, 15(2), 120131.

Palmer, J. W., \& Markus, M. L. (2000). The Performance Impacts of Quick Response and Strategic Alignment in Specialty Retailing. Information Systems Research, 3(3), 241259.

Park, Y., Sawy, O., \& Fiss, P. (2017). The Role of Business Intelligence and Communication Technologies in Organizational Agility: a Configurational Approach. Journal of the Association for Information Systems, 18(9), 648686.

Queiroz, M., Tallon, P. P., Sharma, R., \& Coltman, T. (2018). The Role of IT Application Orchestration Capability in Improving Agility and Performance. Journal of Strategic Information Systems, 27(1), 4-21.
Ravichandran, T. (2018). Exploring the Relationships between IT Competence, Innovation Capacity and Organizational Agility. Journal of Strategic Information Systems, 27(1), 2242.

Richardson, S., Kettinger, W., Banks, M., \& Quintana, Y. (2018). IT and Agility in the Social Enterprise: a Case Study of St. Jude Children's Research Hospital's "Cure4Kids" IT-Platform for International Outreach. Journal of the Association for Information Systems, 15(1), 1-32.

Roberts, N., \& Grover, V. (2012). Leveraging Information Technology Infrastructure to Facilitate a Firm's Customer Agility and Competitive Activity: an Empirical Investigation. Journal of Management Information Systems, 28(4), 231-270.

Sabherwal, R., \& Chan, Y. E. (2001). Alignment between Business and IS Strategies: a Study of Prospectors, Analyzers, and Defenders. Information Systems Research, 12(1), 11-33.

Saha, N., Gregar, A., \& Sáha, P. (2019). Organizational Agility and HRM Strategy: Do They Really Enhance Firms' Competitiveness?. International Journal of Organizational Leadership, 6(3), 323-334.

Sambamurthy, V., Bharadwaj, A., \& Grover, V. (2003). Shaping Agility through Digital Options: Reconceptualizing the Role of Information Technology in Contemporary Firms. MIS quarterly, 27(2), 237-263.

Santos-Vijande, M. L., López-Sánchez, J. Á., \& Trespalacios, J. A. (2012). How Organizational Learning Affects a Firm's Flexibility, Competitive Strategy, and Performance. Journal of Business Research, 65(8), 1079-1089.

Stern, P., \& Hammond, K. (2004). The Relationship between Customer Loyalty and Purchase Incidence. Marketing Letters, 15(1), 5-19.

Sutapa, S., Mulyana, M., \& Wasitowati, W. (2017). The Role of Market Orientation, Creativity and Innovation in Creating Competitive Advantages and Creative Industry Performance. Jurnal Dinamika Manajemen, 8(2), 152-166.

Tallon, P. P. (2008). A Process-Oriented Perspective on the Alignment of Information Technology and Business Strategy. Journal of Management Information Systems, 24(3), 227-268.

Tallon., \& Pinsonneault. (2011). Competing Per- 
Lutfi Nurcholis \& Budhi Cahyono/ The Equilateral Agility Concept as Mediating Variable in Relationship....

spectives on the Link between Strategic Information Technology Alignment and Organizational Agility: Insights from a Mediation Model. MIS Quarterly, 35(2), 463-486.

Tantong, P., Karande, K., Nair, A., \& Singhapakdi, A. (2010). The Effect of Product Adaptation and Market Orientation on Export Performance: a Survey of Thai Managers. The Journal of Marketing Theory and Practice, 18(2), 155-170.

Teece, D., Pisano, G., \& Shuen, A. (1997). Dynamic Capabilities and Strategic Management. Strategic Management Journal, 18(7), 509-533.

Thrassou, A., \& Vrontis, D. (2006). A Small Services Firm Marketing Communications Model for SME-Dominated Environments. Journal of Marketing Communications, 12(3), 183-202.

Tiwana, A., \& Kim, S. K. (2015). Discriminating IT Governance. Information Systems Research, 26(4), 656-674.

Tiwana, A., Konsynski, B., \& Bush, A. A. (2010). Platform Evolution: Coevolution of Platform Architecture, Governance, and Environmental Dynamics. Information Systems Research, 21(4), 675-687.

Tsatsou, P., Elaluf-Calderwood, S., \& Liebenau, J. (2010). Towards a Taxonomy for Regulatory Issues in a Digital Business Ecosystem in the EU. Journal of Information Technology, 25(3), 288-307.

van Oosterhout, M., Waarts, E., \& van Hillegersberg, J. (2006). Change Factors Requiring Agility and Implications for IT. European Journal of Information Systems, 15(2), 132-145.

Vervest, P., Preiss, K., van Heck, E., \& Pau, L.-F. (2004). The Emergence of Smart Business Networks. Journal of Information Technology, 19(4), 228-233.

Vrontis, D., Kogetsidis, H., \& Stavrou, A. (2006). Strategic Marketing Planning for a Supplier of Liquid Food Packaging Products in $\mathrm{Cy}$ - prus. Journal of Business and Industrial Marketing, 21(4), 250-261.

Worren, N., Moore, K., \& Cardona, P. (2002). Modularity, Strategic Flexibility and Firm Performance: a Study of the Home Appliance Industry. Strategic Management Journal, 23(12), 1123-1140.

Yeung, P. K., \& Lau, C. M. (2005). Competitive Actions and Firm Performance of Hotels in Hong Kong. International Journal of Hospitality Management, 24(4), 611-633.

Young-Ybarra, C., \& Wiersema, M. (1999). Strategic Flexibility in Information Technology Alliances: the Influence of Transaction Cost Economics and Social Exchange Theory. Organization Science, 10(4), 439-459.

Yusof, F. M., \& Aziz, R. A. (2008). Strategic Adaptation and the Value of Forecasts: the Development of a Conceptual Framework. Journal of Business Economics and Management, 9(2), 107-114.

Zahra, S. A., \& Covin, J. (1993). Business Strategy, Technology Policy and Firm Performance. Strategic Management Journal., 14(6), 451-478.

Zahra, S. A., \& George, G. (2002). Absorptive capacity: a Review, Reconceptualization, and Extension. Academy of Management Review, 27(2), 185-203.

Zhou, S., Qiao, Z., Du, Q. Wang, G. A., Fan, W., \& Yan, X. (2018). Measuring Customer Agility from Online Reviews Using Big Data Text Analytics. Journal of Management Information Systems, 35(2), 510-539.

Zhou, X., Hanlon, C., Robertson, J., Spaaij, R., Westerbeek, H., Hossack, A., \& Funk, D. C. (2018). Dress for Fit: an Exploration of Female Activewear Consumption. Sport Management Review, 21(4), 403-415.

Zitkiene, R., \& Deksnys, M. (2018). Organizational Agility Conceptual Model. Montenegrin Journal of Economics, 14(2), 115-129. 